\title{
哈尼梯田湿地生态系统健康评价指标体系构建
}

\author{
舒远琴, 宋维峰 ${ }^{*}$,马建刚 \\ 西南林业大学,生态与环境学院, 昆明 650224
}

\begin{abstract}
摘要: 为了获得梯田湿地生态系统健康评价的指标体系, 以云南红河哈尼梯田湿地为例, 基于对该湿地维持机制的分析, 构建了 包括生态特征、功能整合、社会与政治 3 个方面共 20 个指标的健康评价指标体系以及各个指标的健康阈值分级表。同时,利用 AHP 层次分析法确定了各指标的权重, 运用综合评价法对梯田湿地生态系统的健康状态进行评价。本研究构建的评价指标体 系解决了哈尼梯田湿地生态系统缺乏健康评价指标体系和支持理论的问题, 为评价该类型湿地生态系统的健康状态提供指导 方法, 能够依据其评价结果为后续湿地健康质量的提升及湿地的可持续利用发展提出改进策略。
\end{abstract}

关键词:生态系统健康;哈尼梯田;指标体系;健康评价

\section{Establishment of health evaluation index system of Hani Terrace Wetland Ecosystem}

\author{
SHU Yuanqin, SONG Weifeng ${ }^{*}$, MA Jiangang \\ College of the Ecology and Environment, Southwest Forestry University, Kunming 650224, China
}

\begin{abstract}
Wetland plays an extremely important role in maintaining biodiversity, improving water quality, regulating microclimate, and protecting water and soil. With the unreasonable human activities, the ecological problems of wetland are becoming more and more serious, so the evaluation and diagnosis of wetland ecosystem health is extremely urgent. Hani terrace wetland is a special artificial paddy field wetland in southwest mountain area. It has not only important wetland ecological function value, but also agricultural production and national cultural value. At present, the research on Hani terrace wetland ecosystem mainly involves economic culture, ecological security and landscape tourism, while the research on ecosystem health evaluation is few. By analyzing the maintenance mechanism of the ecological balance of Hani terrace wetland and establishing a scientific health evaluation system to evaluate the health of the wetland, we can better understand the health status of the wetland, provide scientific support for the planning and utilization of the wetland and promote the sustainable development of the wetland. The unique vertical spatial structure of forest-village-terrace-river in the Hani terrace wetland is the maintenance mechanism of healthy balance of wetland ecosystem. Each part is independent and indivisible, with integrity. At this time, Hani terrace wetland ecosystem is not only the ecological subsystem of terrace wetland, but also the health evaluation of the whole forest-village-terrace river system. Based on the analysis of the maintenance mechanism, this paper constructed a health evaluation index system of 20 indicators including ecological characteristics, functional integration, social and political aspects and a health threshold grading table of each indicator. Meanwhile, AHP analytic hierarchy process is used to determine the weight of each index, and comprehensive evaluation method is used to evaluate the health status of Hani terrace wetland ecosystem later. The evaluation index system constructed
\end{abstract}

基金项目:云南省基础研究重点项目(202001 AS070042); 国家自然科学基金项目(41371066); 云南省教育厅科学研究基金项目(2020Y0385)

收稿日期:2020-10-22; 网络出版日期:2021-07- 24

* 通讯作者 Corresponding author.E-mail: songwf85@126.com 
in this study solves the problem of the lack of health evaluation index system and provides a guiding method for the evaluation of the health status of this type of wetland ecosystem. According to the evaluation results, improvement strategies can be proposed for the subsequent improvement of wetland health quality and sustainable utilization development of wetlands.

Key Words : ecosystem health assessment; Hani terrrace; indicator system; health assessment

湿地是维持生物多样性, 提供动植物资源生长的重要场所, 是重要的遗传基因库 ${ }^{[1]}$ 。按照《湿地公约》对 湿地类型的划分,我国几乎拥有所有类型的湿地,是世界上湿地资源最丰富的国家之一,湿地面积位列世界第 四 $^{[2]}$ 。由于城市化、工业化进程加剧和生态污染等问题导致我国湿地面积持续降低,湿地生态功遭受能破 坏 ${ }^{[3]}$ 。为保护湿地生态环境, 自 2017 年《全国湿地保护 “十三五” 实施规划》提出以后, 开展了一系列与湿地 生态环境有关的保护与修复工作 ${ }^{[4]}$ 。

我国的人工湿地主要包括城市湿地和水稻田湿地 ${ }^{[5]}$, 其中西南山地梯田是特殊的人工稻田湿地。以云 南红河哈尼梯田湿地为例, 哈尼梯田是传承上千年的典型稻田人工湿地的代表,其作为生态农业不仅具有农 业生产、民族文化价值还具有重要的湿地生态功能价值。然而, 长期以来人们并未将其当做特殊的人工湿地 进行管理研究, 仅仅视其为一种农业耕地。如今, 由于人口迅速增长, 哈尼梯田湿地的开发需求越来越大。一 方面湿地不合理开发利用,湿地景观格局破坏; 另一方面,农业人口流失导致大量梯田弃耕,水田变旱地湿地 面积锐减, 区域生态环境面临的威胁增大 ${ }^{[6]}$ 。在这样的背景下, 评价哈尼梯田湿地生态系统健康现状, 对保 护哈尼梯田湿地的具有重要的意义。

目前, 围绕哈尼梯田湿地生态系统开展的研究主要涉及了梯田文化、生态安全及景观旅游等方面 ${ }^{[7]}$, 而 对湿地系统健康评价的研究处于空白阶段。认识哈尼梯田湿地生态平衡的维持机制,构建科学的健康评价体 系对湿地的可持续发展具有十分重要的意义。

\section{1 哈尼梯田湿地概况}

\section{1 分布}

哈尼梯田湿地位于云南省红河哈尼族彝族自治州南部 $\left(22^{\circ} 33^{\prime}-23^{\circ} 08^{\prime} \mathrm{N}, 101^{\circ} 48^{\prime} 0-103^{\circ} 38^{\prime} \mathrm{E}\right)$, 行政区 划包括红河州的红河、元阳、绿春、金平四个县,规模宏大,面积达到 $7 \times 10^{4} \mathrm{hm}^{2[8]}$ 。该区域地处北回归线以南, 属于亚热带山地季风气候, 干湿季分明,多雾多雨,年降水量 800-1800mm, 全年日照达 $2000 \mathrm{~h}$ 以上,具有良好 的水热资源 ${ }^{[9]}$ 。2007 年被列人国家公园湿地名录,2013 年被联合国教科文组织批准为世界文化遗产 ${ }^{[10]}$ 。

\section{2 维持机制}

梯田湿地是指在水资源丰富的山区,由人工开垦修筑而成的梯级水平稻田，一般采用高山来水自流灌溉， 是人工湿地中的重要类型。哈尼梯田湿地是由哈尼族为主在长期的耕作过程中构建的以种水稻为主的复合 生态系统,包括水源、沟渠、鱼塘、蓄肥池、梯田和河流组成部分。哈尼梯田湿地生态系统为高山峡谷地貌所控 制, 沟渠和河流均呈狭长带状延伸, 由 “森林-村庄-梯田-河流”四位一体结合而成。其中, 梯田湿地广泛分布 于中下山, 是梯田湿地生态系统的主要组成部分 ${ }^{[11]}$ 。

哈尼梯田湿地具有明显的空间垂直结构特征, 从山顶到河道, 由森林生态、村寨生态、湿地生态和溪流 (河流)生态四个生态子系统构成 (图 1) 并各自发挥着重要作用。山顶的森林生态子系统作为天然的绿色水 库涵养水源、积累养分,形成了 “山有多高, 水有多高” 的自流灌溉水源体系, 为其它子系统提供水分和营养元 素; 居民在地势平缓、气候适宜的山腰地带修建村寨, 对其它子系统进行经营管理活动; 村寨的下方开冝梯田, 既方便引水灌溉, 又便于村寨的人畜粪便运输。梯田湿地生态子系统提供了稳定的农业生产基础, 并发挥着 梯田人工湿地的生态功能。 


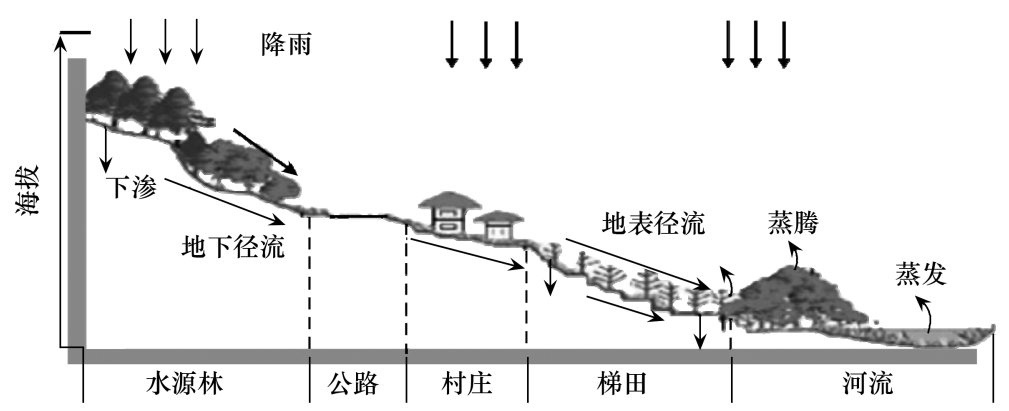

图 1 哈尼梯田系统空间结构 ${ }^{[11]}$

Fig.1 The spatial structure of Hani terrace system

\subsection{1 森林生态子系统}

哈尼梯田顺山势而建, 主要分布在海拔 144-2000m 的群山中, 海拔落差较大, 河谷深切, 山间河流难以 用于梯田湿地的灌溉用水, 顶部森林通过对水资源的分配调节作用, 对梯田和人类生产生活用水进行补给。 研究显示哈尼梯田湿地森林子系统的水源涵养能力高于其他地区, 对该湿地适应极端干旱气候提供保障 ${ }^{[12]}$, 森林储蓄量的不足会导致湿地水资源的欠缺。同时,森林子系统也是自然生物生存繁殖的场所,森林物种多 样性与森林生态服务功能呈正相关性, 能增加森林系统的稳定 ${ }^{[13]}$ 。丰富的物种多样性通过森林生产力传导 机制实现森林水源涵养、保育土壤、固氮释氧、积累营养物质等服务功能能力的提高 ${ }^{[14]}$ 。

\subsection{2 湿地(梯田)生态子系统}

空间结构上处于村寨下部的梯田湿地生态子系统除了净化水质等生态功能还兼具物质生产等经济功能。 梯田的主要污染来自生活污水及农业面源污染。梯田湿地能够改变自然条件下水资源的空间分布格局、迁移 速率和循环等过程通过氨化、反硝化作用等活动, 截留水体中的氮磷物质, 净化水质 ${ }^{[15-16]}$, 是整个系统健康的 动力。有研究表示, 哈尼梯田湿地在空间结构上对氮磷截留作用表现出 “汇” 的景观, 输出为 “兮” 状态, 梯田 截留作用明显 ${ }^{[17]}$ 。流经梯田湿地内部的污水被接纳, 维持了山脚河流的河流生态子系统健康, 对下游生活区 用水安全具有重要的作用。田块间的引水渠是水流、营养元素、沉积物以及污染物质等的空间转移通道。引 水渠系的连通性决定田间水分的运移量和均匀度, 合理的渠系结构能满足梯田湿地的灌溉需求。作为一种廊 道网络, 水渠表现出对湿地生态系统的隔离作用 ${ }^{[18]}$ 。然而, 哈尼梯田湿地天然渠系的良好发展在为水资源分 配提供了基本保障的同时并未割裂梯田景观，一定程度上减少了梯田湿地的破碎化。梯田连绵成片、自然灾 害发生率低是保证景观优美、耕作安全便利的基础。其美学价值以及农业生产创造出来的旅游和物质产出经 济价值不可忽视。值得注意的是, 不科学的旅游发展模式也能导致景观格局的改变, 破坏湿地自然生态环境, 增加人地矛盾 ${ }^{[19]}$ 。

\subsection{3 村寨生态子系统}

哈尼族是哈尼梯田湿地文化的主要创造者 ${ }^{[20]}$ 。人类的干扰活动对生态环境健康和景观结构变化起着主 导作用。湿地农业人口流失造成梯田弃耕, 农业文化失去传承 ${ }^{[21]}$ 。引起农村劳动力转移现象的原因主要有 两种, 一是人口密度过大, 耕地压力增加, 人地矛盾突出。二是外界经济冲击, 当地的农耕经济不能满足人们 的物质生活质量需求。梯田弃耕或者水田变旱地用以种植外来经济作物等人类活动都会导致水田面积缩减, 加剧湿地生态子系统的退化。相反,耕作管理、环保工作的开展、湿地保护意识和人口素质的提升、湿地相关 保护政策法规制度的积极贯彻等积极的人类活动也能促进对哈尼梯田湿地的保护。

整体上, 森林、村寨、湿地与河流四个生态子系统相辅相成, 制约平衡, 是维持哈尼梯田湿地系统健康和永 续利用的根本, 只有保证“四位一体”的维持机制健康才能保证哈尼梯湿地系统的健康。 


\section{2 生态系统健康评价理论基础}

生态系统健康是生态系统一个重要的综合特性,是把生态系统作为生命有机体的一种隐喻。生态系统健 康这一概念产生于 20 世纪 70-80 年代 ${ }^{[22]}$, Rapport 首次全面论述了生态系统健康的内涵 ${ }^{[23]}$, 将生态系统作 为一个整体进行评估,提出了生态系统医学相当于人类、生物有机体的生态系统健康诊断 ${ }^{[24]}$ 。Costanza ${ }^{[25]}$ 从 生态系统特点出发, 明确了生态系统健康是关于 6 个概念的综合: (1) 健康是一种稳态; (2) 健康是没有疾病 的; (3) 健康是系统多要素之间的平衡; (4) 健康是多样性或复杂性; (5) 健康是有活力和可增长空间的; (6) 健康是具有稳定性或可恢复性的。生态系统健康的核心是生态系统结构与功能紊乱的辨识、诊断方案、健康 的评价指标、体系和评价方法 ${ }^{[26]}$ 。生态系统健康主要包括动态性、层级性、创造性、有限性、多样性以及人类 是生态系统的组分等 6 个原理 ${ }^{[27]}$ 。生态系统健康的评价主要包括生态系统本身和人类健康两个方面和多个 层次。

目前, 湿地生态系统健康的评价方法主要是生物法和指标体系法 ${ }^{[28]}$ 。生态系统健康评价可以从生态系 统的活力、组织结构和恢复力 3 个标准出发 ${ }^{[29]}$ 。评价指标主要有活力、恢复力、组织结构、扩散力、服务功能、 管理措施选择、对外部压力的响应以及人类健康影响等 8 个方面 ${ }^{[30-31]}$ 。指标需要遵循整体性、考虑空间尺度 和指标范畴、简明可操作性以及可规范化等选取原则 ${ }^{[32-33]}$ 。

本文选择以构建指标体系的方式评价哈尼梯田湿地系统的健康状态。在构建指标体系过程中, 经济学、 生态学、复合生态系统等学科的理论基础都有具体体现。经济学理论中提到土地经营集约度不能无限制地提 高, 要注重生产技术、科学管理和生产资料投人的应用以提高土地经营效益 ${ }^{[34]}$ 。哈尼梯田湿地是山地农田集 约经营的典范,在健康评价时, 需要考虑土地集约经营的经济问题。研究区的人口素质、湿地管理水平以及生 产资料的投人,例如,农林水等三个方面的投资等都与土地经营效益相关, 是系统活力状态和管理措施的反 映。景观生态学研究景观格局与其生态学过程的相互作用 ${ }^{[35]}$, 其中的稳定性原则强调系统结构与功能之间 长期演替发展的动态平衡 ${ }^{[36]}$ 。根据维持机制的分析, 哈尼梯田湿地的水文调节、物质生产、旅游观光等功能 得以发挥都基于 “四位一体”结构的稳定。在该湿地的健康评价时, 考虑了梯田破碎度、梯田退化率及森林面 积等影响生态系统结构稳定的指标。哈尼梯田湿地系统作为一个复杂的人居整体环境, 人类是整个环境最主 要的创造者, 区域内的人类活动, 尤其是耕作管理活动尤为重要, 哈尼梯田湿地更好地发挥生态功能、物质生 产功能都离不开人类的管理活动。复合生态系统理论强调整体观, 要把人类看做生态系统的一个有机组分, 综合考虑生态环境问题, 才能达到人与自然的高度和谐 ${ }^{[37]}$ 。

\section{3 哈尼梯田湿地系统健康评价指标体系构建}

\section{1 评价指标选取}

本研究基于对生态系统健康评价理论基础和哈尼梯田湿地维持机制的分析,选取了 20 单项指标构建了 关于生态特征、功能整合、社会与政治等 3 方面的健康评价指标体系 (表 1 )。

\subsection{1 生态特征指标}

根据崔保山 ${ }^{[38]}$ 的研究,生态特征指标主要涉及了水环境指标和生物安全指标等。哈尼梯田湿地作为人 工型湿地,除了基本的指标, 如水质、生物多样性指数和外来物种人侵度等指标外,还应该考虑湿地区域内的 渠系连通性、林田比指数、自然灾害率、梯田破碎度和梯田退化率等特征指标, 这些指标是根据哈尼梯田湿地 的特殊性提出的指标,维持机制反映出湿地生态系统的健康状况与这一些指标紧密相关。

(1) 水质

将国家《地表水环境质量标准》水质标准 ${ }^{[39]}$ 的 I - II 类水、III类水、 IV 类水、以及低于 IV 类水的类别将哈 尼梯田湿地地表水质量划分为四大类,分别对应水质指标的优、良、中、差四个健康阈值。

(2) 渠系连通性 
合理的渠系结构布置是哈尼梯田灌溉农业可持续 发展的保障。渠系连通性指标对哈尼梯田湿地系统的 健康有重要意义。根据张兆豪 ${ }^{[40]}$ 和王梅 ${ }^{[41]}$ 等研究, 哈 尼梯田渠系结构数据可通过野外实地调查和快鸟影像 图等方法获得。本文的渠系连通性可从以下几个方面 评价：

水面率 $W_{P}$ 是水面积占区域总面积的比例, 即:

$$
W_{P}=\left(A_{W} / A\right) \times 100 \%
$$

式中, $W_{P}$ 为水面率; $A_{W}$ 为灌区内水体总面积 $\left(\mathrm{km}^{2}\right) ; A$ 为灌区总面积 $\left(\mathrm{km}^{2}\right)$

渠网密度 $R_{d}$ 是单位灌区面积内渠系长度, 即:

$$
R_{d}=L / A
$$

式中, $L$ 为灌区内渠系总长度 $(\mathrm{km}) ; A$ 为灌区总面积 $\left(\mathrm{km}^{2}\right)$

连接度 $\gamma$ 指的是渠系网络的连接条数与最大可能 连接条数之比, 即:

$$
\gamma=\frac{N}{N_{\max }}=\frac{N}{3(V-2)}
$$

式中, $N$ 代表渠网中渠系数量; $V$ 是渠系连接节点数, $V \geqslant 3 ; N_{\text {max }}$ 为最大可能连接数。 $\gamma$ 取值在 $0-1$ 之间, 0 表示节点没有连线, 1 表示每个节点相互连通。对于渠 系网络结构来说, $\gamma$ 取值多在 $1 / 3$ 和 1 之间, 当 $\gamma$ 接近 $1 / 3$ 时,网络呈树状, $\gamma$ 指数越大,网络连接度越好。

(3) 自然灾害率

自然灾害率是湿地系统发生灾害的频率。主要涉及到的自然灾害有滑坡、崩塌、干旱以及病虫害等。通 过统计年鉴数据获得自然灾害率,单位:次/a。

$$
\text { 自然灾害率 }=\text { 灾害发生次数 } / \text { 年 }
$$

(4) 林田比指数

在本文中,林田比指数指标反映森林子系统与湿地子系统之间的水资源量的相关关系,用湿地核心区森 林水源涵养量与梯田灌区需水量的比值来表示, 根据统计资料并利用宋维峰 ${ }^{[42]}$ 、刘效东 ${ }^{[43]}$ 和饶碧玉 ${ }^{[44]}$ 等研 究计算获得该指标,具体计算公式如下:

$$
\text { 林田比指数 }=\frac{A_{s} \times I_{w}}{P_{t}}
$$

式中, $A_{s}$ 为核心区森林总面积; $I_{w}$ 单位面积森林水源涵养量; $P_{t}$ 为梯田总需水量。

(5) 梯田破碎度

梯田破碎度指的是梯田斑块数量与梯田总面积的比值。梯田斑块数据主要来源于刘宗滨 ${ }^{[45]}$ 及王妍 ${ }^{[46]}$ 的研究,在外业调查的基础上,应用 Google Earth 平台,根据解译标志可对梯田斑块目视解译进行数字化处理 以评价该湿地系统内梯田的斑块破碎度。

$$
P D=\frac{\sum N_{i}}{\sum A_{i}}
$$

式中, $P D$ 梯田斑块破碎度, $\sum N_{i}$ 为梯田斑块数量, $\sum A_{i}$ 为梯田斑块总面积,单位:个 $/ \mathrm{hm}^{2}$ 。

(6) 梯田退化率

在哈尼梯田湿地系统中,湿地的退化率主要指的是水梯田转换为其它利用类型土地面积占原始水梯田面 
积的比例。计算公式如下:

梯田退化率 = (梯田转换面积 / 原始梯田总面积 $) \times 100 \%$

(7) 生物多样性指数

根据统计资料并按照《区域生物多样性评价标准》对哈尼梯田湿地生态系统的生物多样性指数 (Biodiversity Index, 简称 BI) 进行评价 ${ }^{[47]}$ 。

(8) 外来物种人侵度

外来人侵物种包括外来人侵动物和外来人侵植物。哈尼梯田湿地的外来物种人侵度数据来源于红河州 相关的生物资源监测报告,实地监测依据云南省地方标准《自然保护区与国家公园生物多样性监测技术规 程》(DB53/T391-2012) 执行。计算公式如下:

$$
E_{I}=\frac{N_{I}}{\left(N_{V}+N_{P}\right)}
$$

式中, $E_{I}$ 为外来物种人侵度; $N_{I}$ 为外来物种入侵种数; $N_{V}$ 为评价区野生动物种数; $N_{P}$ 为评价区野生植物 种数。

3.1.2 功能整合指标

哈尼梯田湿地系统在长期发展过程中已经与当地社会形成了紧密相联的关系,该湿地的功能整合指标除 了主要的生态功能指标, 如水源保证率、水文调节指数等, 还包括了土地生产力水平、旅游观光和物质经济指 数等经济生产功能指标。

(1) 水源保证率

根据张齐立 ${ }^{[48]}$ 对云南程海国家重要湿地的研究,本文选取了水源保证率指标用于表征湿地年水资源量 的稳定性,具体计算公式如下:

$$
\text { 水源保证率 }=(\text { 湿地年可供水资源量 } / \text { 湿地年需水量 }) \times 100 \%
$$

(2) 水文调节指数

水文调节即生态系统能对自然界水的运动变化所发挥作用,改变水在空间、时间、数量等方面的现象与过 程, 如调蓄洪水、消减洪峰等作用 ${ }^{[49]}$ 。本文水文调节指数用湿地区域内能够进行水文调节的地类面积占湿地 总面积的比例来表示 ${ }^{[50]}$ 。

$$
\text { 水文调节指数 }=(\text { 森林面积 }+ \text { 梯田面积 }+ \text { 河流面积 } / \text { 研究区总面积 }) \times 100 \%
$$

(3) 土地生产力水平

从农业生产年收获量的情况来衡量 ${ }^{[51]}$, 单位: $\mathrm{kg} / \mathrm{km}^{2}$ 。

(4) 旅游观光指数

旅游观光指数即旅游强度, 用于反映湿地的旅游发展状况。单位:万人次 $/ \mathrm{a}$ 。

(5) 物质经济指数

物质经济指数用来评价湿地经济生产功能水平及社会经济发展程度 ${ }^{[52]}$, 计算公式如下:

物质经济指数 $=$ 湿地区所在的最小行政单元年总收人 / 总人口

\subsection{3 社会与政治指标}

社会与政治指标对哈尼梯田湿地的健康发展有着重要的意义。人类决策对湿地的健康状况具有极大的 影响, 参考崔保山 ${ }^{[53]}$ 、朱F锦 ${ }^{[54]}$ 及高静湉 ${ }^{[55]}$ 等的研究, 提出如下社会与政治的相关指标, 如人口密度、湿地管 理水平、农药、化肥使用强度等。此外,政治经济政策也是维持本地区湿地系统健康和有效保护湿地资源利用 的关键，如环保投资指数、对湿地保护出台的相关法律法规及贯彻度等指标。

(1) 人口密度

人口密度用单位土地面积人口数量来表示, 单位: 人 $/ \mathrm{m}^{2}$ 。人口密度的健康等级國值通过土地承载力指 数来反映,具体计算如下,等级划分见表 2 : 


$$
\mathrm{LCC}=\frac{G}{G_{P}} ; \mathrm{LCCI}=\frac{P_{a}}{\mathrm{LCC}}
$$

式中, $\mathrm{LCC}$ 为土地承载力 $\left(\right.$ 人); $P$ 为粮食总产量 $(\mathrm{kg}) ; G_{P}$ 为人均粮食消费标准 (中国人均粮食消费标准为 $400 \mathrm{~kg} / \mathrm{a}) ; \mathrm{LCCI}$ 为土地承载力指数; $P_{a}$ 为实际人口数量 ${ }^{[56-57]}$ 。

表 2 土地资源承载力分级标准

Table 2 Evalution criteria for land resource carrying capacity

\begin{tabular}{llll}
\hline \multicolumn{2}{c}{ 土地资源承载力 Carrying capacity of land resources } & $\begin{array}{l}\text { 评价指数 The evaluation index } \\
\text { LCCI }\end{array}$ & $\begin{array}{l}\text { 人均粮食 } / \mathrm{kg} \\
\text { The per capita grain }\end{array}$ \\
\hline 类型 Type & 级别 Level & LCCI $\leqslant 0.5$ & $\geqslant 800$ \\
粮食盈余 & 富富有余 & $0.5<$ LCCI $\leqslant 0.75$ & $533-800$ \\
Food surplus & 富裕 & $0.75<$ LCCI $\leqslant 0.875$ & $457-533$ \\
盈余 & 平衡有余 & $0.875<$ LCCI $\leqslant 1$ & $400-457$ \\
人粮平衡 & 临界超载 & $1<$ LCCI $\leqslant 1.125$ & $356-400$ \\
Food satisfy & 超载 & $1.125<$ LCCI $\leqslant 1.25$ & $320-356$ \\
人口超载 & 过载 & $1.25<$ LCCI $\leqslant 1.5$ & $267-320$ \\
Population overload & 严重超载 & LCCI $>1.5$ & $<267$ \\
\end{tabular}

(2)农业人口流失率

农业人口是哈尼梯田湿地管理队伍最主要的构成,农业人口流失会造成湿地耕作管理活动缺失,引起湿 地生态安全。因此本文选取农业人口流失率作为湿地系统健康评价的指标之一。用从事农业耕作活动的人 口流失数量所占的比例表示,计算公式如下:

$$
\text { 农业人口流失率 }=(\text { 流失的农业人口数量 } / \text { 农业人口总数量 }) \times 100 \%
$$

(3)农药、化肥使用强度

哈尼梯田湿地系统的主要污染来自于农业面源, 根据陈风[ ${ }^{[58]}$ 等选择农药、化肥使用强度作为系统环境污 染的评价指标, 单位 $\mathrm{kg} / \mathrm{hm}^{2}$ 。

\section{(4) 湿地人口素质}

湿地人口素质包括了湿地周边人口和湿地旅游人口对湿地的保护意识以及文化程度。通过统计数据了 解湿地周边人口的文化程度占比以及发放问卷调查的形式了解湿地区有湿地保护意识的人口占比来表示湿 地人口素质的高低程度。

(5) 湿地管理水平

湿地管理水平对哈尼梯田湿地的生态系统健康发挥着比较重要的作用,体现在管理队伍(即从事耕作的 农民、湿地管理的决策人员等) 的整体水平上。

(6) 环保投资指数

环保投资指数为当地政府财政支出中环保类财政支出的占比。该指标侧面反映了湿地生态环境得到当 地政府的重视程度,包括污水处理设施建设投资、水利设施建设投资、农民耕地补贴等。徐国荣 ${ }^{[59]}$ 等利用该 指标评价了甘南尔海湿地的生态系统健康, 计算方式如下:

$$
\text { 环保投资指数 }=(\text { 环保投资方面的财政支出 / 湿地区生产总值 }) \times 100 \%
$$

（7）政策法规贯彻

以当地政府出台的与湿地保护相关的政策法规条例数量及与湿地保护管理相关的政府部门数量来表示 政策法规的贯彻力度。

在所构建的哈尼梯田湿地生态系统健康评价指标体系中,渠系连通性、林田比指数、梯田破碎度、农业人 口流失率等指标是根据梯田湿地的特殊性提出的特征评价指标。 


\section{2 哈尼梯田湿地指标健康阈值划分}

参考国内湿地生态系统健康评价的相关标准 ${ }^{[00-61]}$ 和部分指标现有的国家标准等, 根据哈尼梯田湿地现 状的实际情况,结合相关统计资料的分析对篮选出来的指标进行健康阈值标准分级计算 (表 3-5)。

表 3 生态特征指标健康阈值分级

Table 3 Health threshold classification of ecological characteristics indicators

\begin{tabular}{|c|c|c|c|c|}
\hline \multirow{2}{*}{$\begin{array}{l}\text { 指标 } \\
\text { Index }\end{array}$} & \multicolumn{4}{|c|}{ 阈值等级 Range of threshold } \\
\hline & $\begin{array}{l}\text { 优 Excellent } \\
(4.25-5)\end{array}$ & $\begin{array}{l}\text { 良 Good } \\
(3.50-4.25)\end{array}$ & $\begin{array}{l}\text { 中 Middle } \\
(3.00-3.50)\end{array}$ & $\begin{array}{l}\text { 差 Bad } \\
(0.00-3.00)\end{array}$ \\
\hline $\begin{array}{l}\text { 水质 } \\
\text { Water quality }\end{array}$ & 国标 I 、II 类水 & 国标 IIII类水 & 国标IV类水 & 低于国标IV 类水质 \\
\hline $\begin{array}{l}\text { 渠系连通性 } \\
\text { Canal connectivity }\end{array}$ & $W_{P}>0.8, \gamma$ 指数 $>0.5$, & $\begin{array}{l}0.7<W_{P} \leqslant 0.8,0.35<\gamma \text { 指 } \\
\text { 数 } \leqslant 0.5\end{array}$ & $\begin{array}{l}0.65<W_{P} \leqslant 0.7,0.3<\gamma \text { 指 } \\
\text { 数 } \leqslant 0.35\end{array}$ & $W_{P} \leqslant 0.65, \gamma$ 指数 $\leqslant 0.3$ \\
\hline $\begin{array}{l}\text { 自然灾害率 } \\
\text { Natural disaster rate }\end{array}$ & $\begin{array}{l}\text { 基本不发生自然灾害, 灾 } \\
\text { 害发生频率<2 次 }\end{array}$ & $\begin{array}{l}\text { 全年自然灾害发生频率 } \\
3 \text {-4 次 }\end{array}$ & $\begin{array}{l}\text { 全年自然灾害发生频率 } \\
\text { 为 } 5 \text {-6 次 }\end{array}$ & $\begin{array}{l}\text { 自然灾害发生频繁, 次数> } \\
7 \text { 次 }\end{array}$ \\
\hline $\begin{array}{l}\text { 林田比指数 } \\
\text { Index of the ratio of forest } \\
\text { to terrace }\end{array}$ & $\begin{array}{l}\text { 林田比指数> } 1 \text {;森林蓄积 } \\
\text { 量高, 水源涵养能力高 }\end{array}$ & $\begin{array}{l}\text { 林田比指数 } 0.8-1 \text {, 森 } \\
\text { 林蓄积量较高, 水源涵养 } \\
\text { 能力较高 }\end{array}$ & $\begin{array}{l}\text { 林田比指数 } 0.7-0.8 \text {, 森 } \\
\text { 林蓄积量略显不足 } \\
\text { 水源涵养量一般 }\end{array}$ & $\begin{array}{l}\text { 林田比指数 }<0.6 \text {, 森林蓄积 } \\
\text { 量严重不足 }\end{array}$ \\
\hline $\begin{array}{l}\text { 梯田破碎度 } \\
\text { Terrace } \\
\text { fragmentation index }\end{array}$ & $\begin{array}{l}\text { 梯田湿地景观完整, 破碎 } \\
\text { 度不高 }\end{array}$ & $\begin{array}{l}\text { 梯田湿地景观较完整, 破 } \\
\text { 碎度一般 }\end{array}$ & 梯田湿地景观较破碎 & 梯田湿地景观很破碎 \\
\hline $\begin{array}{l}\text { 梯田退化率 } \\
\text { Terrace degradation index }\end{array}$ & $\begin{array}{l}\text { 水田面积有增加趋势, 湿 } \\
\text { 地率增加 }\end{array}$ & $\begin{array}{l}\text { 水田面积维持稳定,梯田 } \\
\text { 面积无变化 }\end{array}$ & $\begin{array}{l}\text { 水田转化率较高, 湿地面 } \\
\text { 积缩减 }\end{array}$ & $\begin{array}{l}\text { 梯田大量弃耕, 水田旱化 } \\
\text { 严重 }\end{array}$ \\
\hline $\begin{array}{l}\text { 生物多样性指数 } \\
\text { Biodiversity Index }\end{array}$ & $\begin{array}{l}\text { 物种高度丰富, 特有属、 } \\
\text { 特有种多, 生态系统丰富 } \\
\text { 多样; } \mathrm{BI} \geqslant 60\end{array}$ & $\begin{array}{l}\text { 物种较丰富, 特有属、特 } \\
\text { 有种多,生态系统类型较 } \\
\text { 多, 局部地区生物多样性 } \\
\text { 高度丰富; } 30 \leqslant \mathrm{BI}<60\end{array}$ & $\begin{array}{l}\text { 物种较少, 特有属、特有 } \\
\text { 种不多, 局部地区生物多 } \\
\text { 样性较丰富, 但生物多样 } \\
\text { 性总体水平一般; } 20 \leqslant \mathrm{BI} \\
<30\end{array}$ & $\begin{array}{l}\text { 物种贫乏, 生态系统类型单 } \\
\text { 一, 脆弱, 生物多样性极低; } \\
\mathrm{BI}<20\end{array}$ \\
\hline $\begin{array}{l}\text { 外来物种人侵度 } \\
\text { Invasion index of } \\
\text { alien species }\end{array}$ & $\begin{array}{l}\text { 无外来人侵物种, 湿地原 } \\
\text { 生状态保持良好 }\end{array}$ & $\begin{array}{l}\text { 具有外来人侵物种, 种数 } \\
\text { 占所处地区原生物种数 } \\
\text { 的 } 1 \%-3 \%\end{array}$ & $\begin{array}{l}\text { 少量外来人侵物种, } 3 \% \\
\leqslant \text { 人侵物种占比 }<5 \%\end{array}$ & $\begin{array}{l}\text { 人侵物种占比>5\%, 对该区 } \\
\text { 生态安全产生威胁 }\end{array}$ \\
\hline
\end{tabular}

表 4 功能整合指标健康阈值分级

Table 4 Health threshold classification of functional integration indicators

\begin{tabular}{|c|c|c|c|c|}
\hline \multirow{2}{*}{$\begin{array}{l}\text { 指标 } \\
\text { Index }\end{array}$} & \multicolumn{4}{|c|}{ 阈值等级 Range of threshold } \\
\hline & $\begin{array}{l}\text { 优 Excellent } \\
(4.25-5)\end{array}$ & $\begin{array}{l}\text { 良 Good } \\
(3.50-4.25)\end{array}$ & $\begin{array}{l}\text { 中 Middle } \\
(3.00-3.50)\end{array}$ & $\begin{array}{l}\text { 差 } \mathrm{Bad} \\
(0.00-3.00)\end{array}$ \\
\hline $\begin{array}{l}\text { 水源保证率 } \\
\text { Water assurance rate }\end{array}$ & 水源保证率 $\geqslant 80 \%$; & 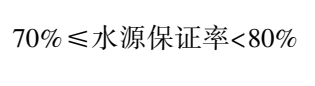 & $60 \% \leqslant$ 水源保证率<70\% & 水源保证率<60\% \\
\hline $\begin{array}{l}\text { 水文调节指数 } \\
\text { Hydrological regulation index }\end{array}$ & 水文调节指数 $\geqslant 80 \%$ & $\begin{array}{l}65 \% \leqslant \text { 水文调节指数 } \\
<80 \%\end{array}$ & $\begin{array}{l}50 \% \leqslant \text { 水文调节指数 } \\
<65 \%\end{array}$ & 水文调节指数 $<50 \%$ \\
\hline $\begin{array}{l}\text { 土地生产力水平 } \\
\text { Land productivity }\end{array}$ & $>8910 \mathrm{~kg} / \mathrm{km}^{2}$ & $\begin{array}{l}5090<土 \text { 地生产力水平 } \leqslant \\
8910 \mathrm{~kg} / \mathrm{km}^{2}\end{array}$ & $\begin{array}{l}4455<土 \text { 地生产力水平 } \leqslant \\
5090 \mathrm{~kg} / \mathrm{km}^{2}\end{array}$ & $\leqslant 4455 \mathrm{~kg} / \mathrm{km}^{2}$ \\
\hline $\begin{array}{l}\text { 旅游观光指数 } \\
\text { Tourism index }\end{array}$ & $<1720$ 万人次 $/ \mathrm{a}$ & $\begin{array}{l}1720 \leqslant \text { 旅游观光指数 }< \\
1746 \text { 万人次 } / \mathrm{a}\end{array}$ & $\begin{array}{l}1746 \leqslant \text { 旅游观光指数 }< \\
1759 \text { 万人次 } / \mathrm{a}\end{array}$ & $\geqslant 1759$ 万人次 $/ a$ \\
\hline $\begin{array}{l}\text { 物质经济指数 } \\
\text { Material economy index }\end{array}$ & $>10000$ 元 & $\begin{array}{l}9000<\text { 物质经济指数 } \leqslant \\
10000 \text { 元 }\end{array}$ & $\begin{array}{l}8000<\text { 物质经济指数 } \leqslant \\
9000 \text { 元 }\end{array}$ & $\leqslant 8000$ 元 \\
\hline
\end{tabular}


表 5 社会与政治指标健康阈值分级

Table 5 Health threshold classification for social and political indicators

\begin{tabular}{|c|c|c|c|c|}
\hline \multirow{2}{*}{$\begin{array}{l}\text { 指标 } \\
\text { Index }\end{array}$} & \multicolumn{4}{|c|}{ 阈值等级 Range of threshold } \\
\hline & $\begin{array}{l}\text { 优 Excellent } \\
(4.25-5)\end{array}$ & $\begin{array}{l}\text { 良 Good } \\
(3.50-4.25)\end{array}$ & $\begin{array}{l}\text { 中 Middle } \\
(3.00-3.50)\end{array}$ & $\begin{array}{l}\text { 差 Bad } \\
(0.00-3.00)\end{array}$ \\
\hline $\begin{array}{l}\text { 人口密度 } \\
\text { Population density }\end{array}$ & $\begin{array}{l}\text { 土地资源承载力 } \leqslant 0.75, \\
\text { 人口密度小, 处于粮食富 } \\
\text { 裕状态 }\end{array}$ & $\begin{array}{l}\text { 土地资源承载力 } \leqslant 1 \text {, 人 } \\
\text { 口密度合理, 处于粮食平 } \\
\text { 衡有余状态 }\end{array}$ & $\begin{array}{l}\text { 土地资 源 承载力 } \leqslant 1 . \\
125, \text { 人口密度较大, 处于 } \\
\text { 人粮平衡临界超载状态 }\end{array}$ & $\begin{array}{l}\text { 土地资源承载力 }>1.125 \text {, 人 } \\
\text { 口密度大, 人口超载, 人粮 } \\
\text { 无法满足平衡 }\end{array}$ \\
\hline $\begin{array}{l}\text { 农业人口流失率 } \\
\text { Agricultural population } \\
\text { turnover rate }\end{array}$ & $\begin{array}{l}\text { 农业人口增加, 流失率为 } \\
\text { 负, 湿地区城镇化率降 } \\
\text { 低,梯田湿地农业文化传 } \\
\text { 承性强 }\end{array}$ & $\begin{array}{l}\text { 农业人口维持不变, 流失 } \\
\text { 率等于零, 城镇化率低, } \\
\text { 梯田湿地农业文化传承 } \\
\text { 性较强 }\end{array}$ & $\begin{array}{l}\text { 农业人口降低, 劳动力流 } \\
\text { 失, 梯田湿地农业文化传 } \\
\text { 承性小 }\end{array}$ & $\begin{array}{l}\text { 城镇化增长率高, 农业人口 } \\
\text { 大量流失, 梯田湿地农业文 } \\
\text { 化传承性极小 }\end{array}$ \\
\hline $\begin{array}{l}\text { 农药化肥使用强度 } \\
\text { Utilization intensity of } \\
\text { chemical fertilizers } \\
\text { and pesticides }\end{array}$ & $\begin{array}{l}\text { 化肥农药使用强度低于 } \\
\text { 云南省均值的 30\% }\end{array}$ & $\begin{array}{l}\text { 化肥农药使用强度低于 } \\
\text { 云南省均值的 } 20 \%\end{array}$ & $\begin{array}{l}\text { 化肥农药使用强度与云 } \\
\text { 南省均值处于同一强度 }\end{array}$ & $\begin{array}{l}\text { 化肥农药使用强度高于云 } \\
\text { 南省均值 }\end{array}$ \\
\hline $\begin{array}{l}\text { 湿地人口素质 } \\
\text { Quality of wetland } \\
\text { population }\end{array}$ & $\begin{array}{l}\text { 文盲率<20\%,90\% 及以 } \\
\text { 上的居民均具有湿地保 } \\
\text { 护意识 }\end{array}$ & $\begin{array}{l}\text { 文盲率<30\%,80\% 的居 } \\
\text { 民具有湿地保护意识 }\end{array}$ & $\begin{array}{l}\text { 文盲率> } 40 \% \text {, 但 } 70 \% \text { 的 } \\
\text { 居民具体湿地保护意识 }\end{array}$ & $\begin{array}{l}\text { 文盲率> } 50 \% \text {, 缺乏湿地保 } \\
\text { 护意识 }\end{array}$ \\
\hline $\begin{array}{l}\text { 环保投资指数 } \\
\text { Environmental } \\
\text { Investment Index }\end{array}$ & $\begin{array}{l}\text { 环保投资指数高,占比高 } \\
\text { 于财政支出 } 25 \%\end{array}$ & 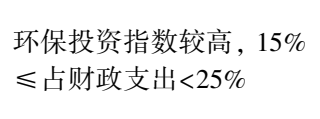 & $\begin{array}{l}\text { 环保投资指数一般, } 10 \% \\
\leqslant \text { 占比 }<15 \%\end{array}$ & $\begin{array}{l}\text { 环保投资指数 低, 占比 } \\
<10 \%\end{array}$ \\
\hline $\begin{array}{l}\text { 湿地管理水平 } \\
\text { Level of Wetland } \\
\text { Management }\end{array}$ & $\begin{array}{l}\text { 管理手段科学合理,管理 } \\
\text { 队伍素质高 }\end{array}$ & $\begin{array}{l}\text { 管理手段较合理,管理队 } \\
\text { 伍素质较高 }\end{array}$ & $\begin{array}{l}\text { 管理手段一般,有相应的 } \\
\text { 管理方法但管理队伍素 } \\
\text { 质缺乏必要培训 }\end{array}$ & $\begin{array}{l}\text { 管理手段落后,管理队伍素 } \\
\text { 质不高 }\end{array}$ \\
\hline $\begin{array}{l}\text { 政策法规贯彻 } \\
\text { Implementation of policies } \\
\text { and regulations }\end{array}$ & $\begin{array}{l}\text { 全面贯彻,立法体系全面 } \\
\text { 完善 }\end{array}$ & $\begin{array}{l}\text { 比较认真贯彻相关法规, } \\
\text { 立法体系完善 }\end{array}$ & $\begin{array}{l}\text { 贯彻力度一般,立法体系 } \\
\text { 较完善 }\end{array}$ & $\begin{array}{l}\text { 没有认真贯彻相关法规,立 } \\
\text { 法体系也不够全面和完善 }\end{array}$ \\
\hline
\end{tabular}

3.3 哈尼梯田湿地生态系统健康评价

\subsection{1 指标权重的确定}

本文利用层次分析法 (Analytic Hierarchy Process, 简称 AHP) 确定指标的权重。其中,各个指标的相对重 要性通过发放问卷调查的方式,咨询 20 位专家意见获得。此 20 位专家由国家高原湿地研究中心、西南林业 大学生态与环境学院、湿地学院、林学院的相关教授、副教授组成, 涉及了生态学、环境科学、林学和水土保持 学等学科。将同一层指标两两比较可判断指标相对重要性并用数值形式表现出来(表 6)。利用软件 YAAHP 10.3 构建判断矩阵 (表 7-10), 确定各指标的权重 $(\text { 表 } 11)^{[62-65]}$ 。

表 6 判断矩阵标度及含义

Table 6 Judgement matrix scale and implication

\begin{tabular}{cl||cl}
\hline 标度 Scale & 含义 Meaning & 标度 Scale & 含义 Meaning \\
\hline 1 & 两个指标相比,具有同等重要性 & 7 & 两个指标相比,一个指标比另一个非常重要 \\
3 & 两个指标相比,一个指标比另一个稍微重要 & 9 & 两个指标相比,一个指标比另一个极端重要 \\
5 & 两个指标相比,一个指标比另一个明显重要 & $2 、 4 、 6 、$ & 重要程度介于两个相邻的等级之间 \\
\hline
\end{tabular}

说明: 如果是后者对前者的重要性则是标度的倒数

表 7 准则层 $\mathbf{B}$ 对目标层 $\mathbf{A}$ 的判断矩阵

Table 7 Criteria layer $B$ for the judgement matrix of $A$

\begin{tabular}{cccc||cccc}
\hline A & B1 & B2 & B3 & A & B1 & B2 & B3 \\
\hline B1 & 1 & 1 & 2 & B3 & $1 / 2$ & 1 & 1 \\
B2 & 1 & 1 & 1 & & & & \\
\hline
\end{tabular}

说明:一致性比例 $0.0516<0.1$, 通过一致性检验 
表 8 指标层 $\mathbf{C}$ 准则层 $\mathbf{B} 1$ 的判断矩阵

Table 8 Index layer $\mathrm{C}$ for the judgement matrix of $\mathrm{B} 1$

\begin{tabular}{|c|c|c|c|c|c|c|c|c|}
\hline B1 & $\mathrm{C} 1$ & $\mathrm{C} 2$ & $\mathrm{C} 3$ & $\mathrm{C} 4$ & C5 & C6 & C7 & $\mathrm{C} 8$ \\
\hline C1 & 1 & $1 / 5$ & 5 & $1 / 4$ & $1 / 2$ & $1 / 3$ & 1 & 5 \\
\hline $\mathrm{C} 2$ & 5 & 1 & 7 & $1 / 3$ & 4 & 3 & 3 & 5 \\
\hline $\mathrm{C} 3$ & $1 / 2$ & $1 / 7$ & 1 & $1 / 6$ & $1 / 3$ & 0.2 & $1 / 5$ & 2 \\
\hline $\mathrm{C} 4$ & 4 & 3 & 6 & 1 & 1 & 4 & 2 & 5 \\
\hline C5 & 2 & $1 / 4$ & 3 & 1 & 1 & 3 & 2 & 5 \\
\hline C6 & 3 & $1 / 3$ & 5 & $1 / 4$ & $1 / 3$ & 1 & 2 & 4 \\
\hline C7 & 1 & $1 / 3$ & 5 & $1 / 2$ & $1 / 2$ & 0.5 & 1 & 5 \\
\hline C8 & $01 / 5$ & 0.2 & 0.5 & $1 / 5$ & $1 / 5$ & 0.25 & $1 / 5$ & 1 \\
\hline
\end{tabular}

说明: 一致性比例 $0.0963<0.1$, 通过一致性检验

表 9 指标层 $\mathbf{C}$ 准则层 $\mathbf{B} 2$ 的判断矩阵

Table 9 Index layer $\mathrm{C}$ for the judgement matrix of $\mathrm{B2}$

\begin{tabular}{lccccc}
\hline B2 & C9 & C10 & C11 & C12 & C13 \\
\hline C9 & 1 & 1 & 2 & 5 & 6 \\
C10 & 1 & 1 & 4 & 2 & 6 \\
C11 & $1 / 2$ & $1 / 4$ & 1 & 1 & 3 \\
C12 & $1 / 5$ & $1 / 5$ & $1 / 2$ & $1 / 2$ & 2 \\
C13 & $1 / 6$ & $1 / 6$ & $1 / 3$ & 1 \\
\hline
\end{tabular}

说明: 一致性比例 $0.0165<0.1$, 通过一致性检验

表 10 指标层 $\mathrm{C}$ 准则层 $\mathrm{B3}$ 的判断矩阵

Table 10 Index layer $\mathrm{C}$ for the judgement matrix of $\mathrm{B3}$

\begin{tabular}{|c|c|c|c|c|c|c|c|}
\hline B3 & C14 & C15 & C16 & C17 & C18 & C19 & C20 \\
\hline C14 & 1 & $1 / 5$ & 2 & 3 & $1 / 4$ & $1 / 4$ & $1 / 3$ \\
\hline C15 & 5 & 1 & 5 & 5 & 5 & 5 & 3 \\
\hline C16 & $1 / 2$ & $1 / 5$ & 1 & $1 / 2$ & $1 / 3$ & $1 / 5$ & $1 / 4$ \\
\hline C17 & $1 / 3$ & $1 / 5$ & 2 & 1 & $1 / 6$ & $1 / 6$ & $1 / 4$ \\
\hline C18 & 4 & $1 / 5$ & 3 & 6 & 1 & 1 & $1 / 3$ \\
\hline C19 & 4 & $1 / 5$ & 5 & 6 & 1 & 1 & $1 / 3$ \\
\hline $\mathrm{C} 20$ & 3 & $1 / 3$ & 4 & 4 & 3 & 3 & 1 \\
\hline
\end{tabular}

说明:一致性比例 $0.0962<0.1$, 通过一致性检验

表 11 哈尼梯田湿地生态系统健康评价指标的权重

Table 11 Weights of ecosystem health assessment indicators of Hani terrace Wetland

\begin{tabular}{|c|c|c|c|c|c|c|c|}
\hline $\begin{array}{l}\text { 准则层 } \\
\text { Criteria layer }\end{array}$ & $\begin{array}{c}\text { 权重 } \\
\text { Weight }\end{array}$ & $\begin{array}{l}\text { 指标层 } \\
\text { Index layer }\end{array}$ & $\begin{array}{c}\text { 权重 } \\
\text { Weight }\end{array}$ & $\begin{array}{l}\text { 准则层 } \\
\text { Criteria layer }\end{array}$ & $\begin{array}{c}\text { 权重 } \\
\text { Weight }\end{array}$ & $\begin{array}{l}\text { 指标层 } \\
\text { Index layer }\end{array}$ & $\begin{array}{c}\text { 权重 } \\
\text { Weight }\end{array}$ \\
\hline 生态特征 & 0.4126 & 水质 & 0.0311 & & & 土地生产力 & 0.0463 \\
\hline \multirow[t]{7}{*}{ Ecological features } & & 渠系连通性 & 0.1040 & & & 旅游观光指数 & 0.0256 \\
\hline & & 自然灾害率 & 0.0124 & & & 物质经济指数 & 0.0167 \\
\hline & & 林田比指数 & 0.1106 & 社会与政治 & 0.2599 & 人口密度 & 0.0156 \\
\hline & & 梯田破碎度 & 0.0625 & Society and Politics & & 农业人口流失率 & 0.1011 \\
\hline & & 梯田退化率 & 0.0446 & & & 农药化肥使用强度 & 0.0096 \\
\hline & & 生物多样性指数 & 0.0366 & & & 湿地人口素质 & 0.0103 \\
\hline & & 外来物种人侵度 & 0.0109 & & & 环保投资指数 & 0.0334 \\
\hline 功能整合 & 0.3275 & 水源保证率 & 0.1103 & & & 湿地管理水平 & 0.0359 \\
\hline Functional integration & & 水文调节指数 & 0.1286 & & & 政策法规贯彻 & 0.0542 \\
\hline
\end{tabular}




\subsection{2 指标健康等级划分及阈值赋分}

在查阅相关文献评价标准并结合实际情况的基础上,将哈尼梯田湿地生态系统健康评价标准分为 4 个等 级,对每个等级区间赋分, 每个指标总分值满分为 5 分, 分别为优 (4.25-5)、良 (3.50-4.25)、中 (3.00$3.50)$ 、差 $(0.00-3.00)$, 能根据算术平均法在各区间内依据指标现状进行评分 ${ }^{[66]}$ 。

\subsection{3 综合评价}

将 20 个指标现状所得分值乘以各指标权重,所有项之和乘以 20 即是哈尼梯田湿地的健康评价综合得 分,具体计算公式如下:

$$
R=\left(\sum_{i=1}^{n} W_{i} F_{i}\right) \times 20
$$

式中, $R$ 表示评价的综合得分; $W_{i}$ 表示第 $i$ 项指标的权重; $F_{i}$ 表示第 $i$ 项指标评分。依据 $R$ 的得分将哈尼梯田 湿地生态系统的健康状况分为健康、亚健康、一般、脆弱、病态五个等级 (表 12)。

表 12 哈尼梯田湿地健康等级划分标准

Table 12 Health grading standard of Hani terrace Wetland

\begin{tabular}{|c|c|c|}
\hline $\begin{array}{l}\text { 生态系统健康等级 } \\
\text { Ecosystem health level }\end{array}$ & $\begin{array}{l}\text { 生态系统健康得分 } \\
\text { Ecosystem health score }\end{array}$ & $\begin{array}{l}\text { 生态系统特征 } \\
\text { Ecosystem Characteristics }\end{array}$ \\
\hline $\begin{array}{l}\text { 健康 } \\
\text { Health }\end{array}$ & $90-100$ & $\begin{array}{l}\text { 湿地资源丰富、组织结构优良、活力极强; 受胁迫程度低, 人类管理水 } \\
\text { 平高 }\end{array}$ \\
\hline $\begin{array}{l}\text { 亚健康 } \\
\text { Sub-health }\end{array}$ & $80-90$ & $\begin{array}{l}\text { 湿地资源较丰富、组织结构优良、活力较强; 受胁迫程度相对较低、人 } \\
\text { 管理水平较高 }\end{array}$ \\
\hline $\begin{array}{l}\text { 一般 } \\
\text { General }\end{array}$ & $70-80$ & $\begin{array}{l}\text { 湿地资源与组织结构一般、活力退化; 受胁迫程度较高, 人类管理水平 } \\
\text { 相对较低 }\end{array}$ \\
\hline $\begin{array}{l}\text { 脆弱 } \\
\text { Fragile }\end{array}$ & $60-70$ & $\begin{array}{l}\text { 湿地资源不足、组织结构破碎、活力较低, 出现生态异常; 受胁迫程度 } \\
\text { 高, 人类管理水平不能满足湿地健康要求 }\end{array}$ \\
\hline $\begin{array}{l}\text { 病态 } \\
\text { Pathological }\end{array}$ & $<60$ & $\begin{array}{l}\text { 湿地资源惯乏、组织结构极其不合理, 活力功能几乎完全丧失; 受胁迫 } \\
\text { 程度极大,人类几乎放弃湿地管理 }\end{array}$ \\
\hline
\end{tabular}

\section{4 讨论与结论}

(1) 湿地生态系统是一个复杂的非线性系统 ${ }^{[67]}$, 不同类型湿地的健康评价在选取关键指标和标准时具有 差异。哈尼梯田湿地作为一种特殊的人工稻田湿地, 其独特的立体空间结构是它与平原稻田湿地区别的根 本。系统结构与功能相互依存, 结构是功能的基础, 功能是结构的表现。哈尼梯田湿地系统的健康是 “四素 同构” 整体结构的健康表现, 四个子生态系统之间的相互作用关系复杂, 各部分独立但不可分割, 具有整体 性。此时的哈尼梯田湿地系统健康评价不仅仅是对梯田湿地生态子系统的健康评价而是对整个森林-村寨梯田-河流的健康评价, 缺一不可。

(2) 与其它湿地系统的健康评价 ${ }^{[68-70]}$ 研究相比较 (表 13), 哈尼梯田湿地系统的健康是垂直空间结构上 四个生态子系统健康的反映, 因此,该湿地系统的评价是二维立体的, 需要从纵向与横向开展研究。纵向考虑 各子系统的相互影响联系, 例如, 森林子系统水源涵养能力与湿地子系统水文的联系, 村寨子系统的耕作管理 活动对湿地子系统的影响等。横向则考虑各子系统健康的基本要素, 例如, 渠系连通性对于梯田灌区内部水 资源分布的影响等。只有结合纵横两个方向选取指标, 构建评价体系才能保证哈尼梯田湿地系统健康评价的 科学完整。

(3) 本研究计算出各个指标的健康阈值, 并将阈值分为优、良、中、差 4 个等级, 每个指标赋分 5 分。各个 单项指标的健康阈值为湿地系统的健康评价时对指标现状评价打分提供了依据。获得了各个指标的评分后 可利用综合评价法计算出哈尼梯田湿地系统健康的总体得分。依据总得分情况可以将哈尼梯田湿地生态系 统健康分为健康、亚健康、一般、脆弱和病态 5 个等级, 获得湿地系统健康评价最终结果。 


\begin{tabular}{|c|c|c|c|c|}
\hline \multicolumn{5}{|c|}{ 表 13 不同湿地生态系统健康评价对比 } \\
\hline \multicolumn{5}{|c|}{ Table 13 Health evaluation of different Wetland ecosystems } \\
\hline 湿地名称 & 类型 & 系统结构 & 主要特征 & 评价方法 \\
\hline Name & Type & System structure & Main characteristics & Evaluation method \\
\hline $\begin{array}{l}\text { 哈尼梯田湿地 } \\
\text { Hani Terraced Wetland }\end{array}$ & 梯田湿地 & $\begin{array}{l}\text { 海拔高差大, 垂直立体 } \\
\text { 结构 }\end{array}$ & $\begin{array}{l}\text { 山地梯田农业经济生产 } \\
\text { 和生态功能 }\end{array}$ & $\begin{array}{l}\text { 复合生态系统, 指标选取涉 } \\
\text { 及纵、横两个层面 }\end{array}$ \\
\hline $\begin{array}{l}\text { 漳江口红树林湿地 } \\
\text { Zhang Jiang Estuary } \\
\text { Mangrove Wetland }\end{array}$ & 沿海滩涂、沼泽平原湿地 & 高差不大,呈平面展布 & $\begin{array}{l}\text { 红树林及互花米草等特 } \\
\text { 征植物 }\end{array}$ & $\begin{array}{l}\text { 基于 GIS 和 RS 遥感数据的 } \\
\text { 健康评价, 特征压力指标为 } \\
\text { 互花米草干扰强度指标 }\end{array}$ \\
\hline $\begin{array}{l}\text { 三门峡库区湿地 } \\
\text { San Menxia Reservoir } \\
\text { Area Wetland }\end{array}$ & $\begin{array}{l}\text { 河流、滩地、湖泊及沼泽 } \\
\text { 等多种天然湿地 }\end{array}$ & 海拔高差不大 & $\begin{array}{l}\text { 珍惜野生动物越冬栖息 } \\
\text { 地, 拥有重要的生态功能 }\end{array}$ & $\begin{array}{l}\text { PSR 指标体系法, 从压力-状 } \\
\text { 态响应 } 3 \text { 个层面选取对应 } \\
\text { 指标进行评价 }\end{array}$ \\
\hline $\begin{array}{l}\text { 雄安湿地 } \\
\text { Xiong'an wetland }\end{array}$ & 城市湿地 & 呈平面展布 & $\begin{array}{l}\text { 构建绿色生态宜居新城 } \\
\text { 区, 疏解北京的非首都 } \\
\text { 功能 }\end{array}$ & $\begin{array}{l}\text { 基于景观格局特征及人类 } \\
\text { 活动, 比如开发系数与人口 } \\
\text { 密度等压力指标分析健康 } \\
\text { 状况 }\end{array}$ \\
\hline
\end{tabular}

(4) 哈尼梯田湿地生态系统的结构及地理位置的特殊性,决定了该指标体系的构建具有针对性,适用于 山地梯田湿地。因此, 在实践应用中可根据评价对象适当调整部分指标及其健康阈值再加以运用。

\section{参考文献 ( References) :}

[ 1 ] 王瑞山, 王毅勇, 杨青, 杨桂谦, 张光, 刘滨华. 我国湿地资源现状、问题及对策. 资源科学, 2000, 22(1)：9-13.

[ 2 ] 王䖵,林慧龙. 中国内陆天然湿地的类型特征及分布规律- I 类的划分. 草业学报, 2012 (1):266-276.

[ 3 ] 徐慧博, 乔红娟, 雷茵茹. 中国湿地保护现状问题及对策分析. 南方农业, 2018, 12 (19): 19-20, 23-23.

[ 4 ] 安树青, 张轩波, 张海飞, 沈美亚, 王怡道. 中国湿地保护恢复策略研究。湿地科学与管理, 2019, 15(2) : 41-44.

[ 5 ] 孙志高, 刘景双, 李涁. 中国湿地资源的现状、问题与可持续利用对策. 干旱区资源与环境, 2006, 20(2)：83-88.

[ 6 ] 王清华. 红河哈尼梯田生态及景观的现代修复. 思想战线, 2016, 42(2) : 25-30.

[ 7 ] 舒远琴, 宋维峰. 我国湿地生态系统健康评价研究进展. 亚热带水土保持, 2020, 32(2): 21-25.

[ 8 ] 宋维峰, 吴锦奎. 哈尼梯田: 历史现状、生态环境、持续发展. 北京: 科学出版社, 2016:2-3.

[ 9 ] 李荣, 宋维峰. 哈尼梯田生态系统土壤微生物量碳的影响因素. 生态学报, 2020, 40(17)：6223-6232.

[10] 刘志林, 丁银平, 角媛梅, 刘澄静. 红河哈尼梯田潜在弃耕风险耕地识别及其主要影响因子. 中国生态农业学报 (中英文), 2020, 28 (1) : 124-135.

[11] 姚敏, 崔保山. 哈尼梯田湿地生态系统的垂直特征. 生态学报, 2006, 26(7) : 2115-2124.

[12] 白艳莹, 闵庆文, 李静. 哈尼梯田生态系统森林土壤水源涵养功能分析. 水土保持研究, 2016, 23(2): 166-170.

[13] 郭文月, 沈文星. 森林植物物种多样性价值形成机理及评价方法. 世界林业研究, 2020, 33(4): 118-122.

[14] Sharma C M, Baduni N P, Gairola S, Ghildiyal S K, Suyal S. Tree diversity and carbon stocks of some major forest types of Garhwal Himalaya, India. Forest Ecology and Management, 2010, 260(12): 2170-2179.

[15] 詹鹏. 梯田式人工湿地处理生活污水处理研究 $[\mathrm{D}]$. 长沙: 湖南大学, 2007.

[16] 金晶, 张饮江. 净水梯田生态环境效应研究进展. 乡村科技, 2020, (13) : 114-117.

[17] 闵惠琳, 宋维峰. 哈尼梯田生态系统地表水不同形态氮含量时空分布特征. 水土保持学报, 2018, 32(3)：235-241.

[18] 陆琦, 马克明, 倪红伟. 湿地农田渠系的生态环境影响研究综述. 生态学报, 2007, 27(5): 2118-2125.

[19] 张永勋, 闵庆文. 稻作梯田农业文化遗产保护研究综述. 中国生态农业学报, 2016, 24(4) : 460-469.

[20] 陆祥宇. 稻作传统与哈尼梯田文化景观保护研究 [D]. 北京: 清华大学, 2012.

[21] 马泽波. 农业劳动力转移对农业文化遗产保护和传承的影响——基于哈尼梯田生态区 4 县 8 镇 16 村的调查. 农业考古, 2019，(1)： 251-259.

[22] 李瑾, 安树青, 程小莉, 王云静, 卓元午. 生态系统健康评价的研究进展. 植物生态学报, 2001, 25(6): 641-647.

[23] Rapport D J. What constitutes ecosystem health? Perspectives in Biology and Medicine, 1989, 33(1) : 120- 132.

[24] Rapport D J. State of ecosystem medicine//Cairns V W, Hodson P V, Nriagu J O, eds. Contaminant Effects on Fisheries. New York: John Wiley and Sons, 1984: 315-324.

[25] Costanza R. Toward an operational definition of ecosystem health. In:Costanza R, Norton B G, Haskell B D, eds. Ecosystem health: New goals for environmental management. Washington DC: Island Press, 1992: 239-256.

[26] 孔红梅, 赵景柱, 姬兰柱, 陆兆华, 邓红兵, 马克明, 张萍. 生态系统健康评价方法初探. 应用生态学报, 2002, 13(4) : 486-490.

[27] 蔡晓明, 蔡博峰. 生态系统的理论和实践. 北京: 化学工业出版社, 2012:289-298. 
[28］周静, 万荣荣. 湿地生态系统健康评价方法研究进展. 生态科学, 2018, 37(6) : 209-216.

[29] 傅伯杰, 刘世梁, 马克明. 生态系统综合评价的内容与方法. 生态学报, 2001, 21(11): 1885-1892.

[30] Rapport D J, Thorpe C, Regier H A. Ecosystem medicine. Bulletin of the Ecological Society of American, 1979, 60(4) : $180-182$.

[31］肖风劲，欧阳华. 生态系统健康及其评价指标和方法. 自然资源学报, 2002, 17(2) : 203-209.

[32］袁兴中, 刘红, 陆健健. 生态系统健康评价一一概念构架与指标选择. 应用生态学报, 2001，12(4)：627-629.

[33] 汪朝辉, 王克林, 许联芳. 湿地生态系统健康评估指标体系研究. 国土与自然资源研究, 2003, (4) : 63-64.

[34] 王春霞, 刘胜, 杨庆媛. 土地集约经营的经济学原理及途径探讨. 安徽农业科学, 2006, 34(13) : 3225-3227.

[35] 邬建国. 景观生态学——概念与理论. 生态学杂志, 2000, 19(1) : 42-52.

[36] 曹宇, 王嘉怡, 李国显. 国土空间生态修复: 概念思辨与理论认知. 中国土地科学, 2019, 33(7) : 1- 10.

[37] 马克明, 孔红梅, 关文涁, 傅伯杰. 生态系统健康评价: 方法与方向. 生态学报, 2001, 21 (12): 2106-2116.

[38］崔保山, 杨志峰. 湿地生态系统健康评价指标体系 I. 理论. 生态学报, 2002, 22(7) : 1005-1011.

[39] 国家环境保护总局, 国家质量监督检验检疫总局. GB 3838-2002 地表水环境质量标准. 北京: 中国环境科学出版社, 2002.

[40] 张兆豪, 宋维峰. 基于无人机遥感的元阳梯田典型灌区渠系结构特征. 水土保持研究, 2020, 27(4): 220-224.

[41] 王梅. 哈尼梯田典型灌排系统连通性评价及其保护研究 [D ]. 昆明: 云南师范大学, 2017.

[42] 陈治成, 宋维峰, 魏峥, 马菁, 刘宗滨. 元阳梯田水源区优势树种枯落物水文特性. 水土保持研究, 2017, 24(1): 135-139.

[43] 刘效东, 龙风玲, 陈修治, 褚国伟, 张倩媚. 基于修正的 Gash 模型对南亚热带季风常绿阔叶林林冠截留的模拟. 生态学杂志, 2016, 35 (11) : 3118-3125.

［44］韩英, 绕碧玉, 周彩霞. 元阳哈尼梯田灌区生态环境需水量初步研究. 中国农村水利水电, 2008, (2) : 31-33, 36-36.

[45］刘宗滨, 宋维峰, 马菁. 红河哈尼梯田空间分布特征研究. 西南林业大学学报, 2016, 36(3)：153-157.

[46] 王妍, 张超, 宋维峰, 和弦, 张少东. 元阳梯田空间分布特征研究. 水土保持研究, 2013, 20(2) : 103-107.

[47］中华人民共和国国家环境保护部. HJ 623-2011 区域生物多样性评价标准. 北京: 油气田环境保护出版社, 2012.

[48］张齐立, 张法强, 戴柔毅, 王梦琳. 云南程海国家重要湿地生态系统健康评价. 湿地科学与管理, 2018, 14(3)：19-22.

[49] 吕一河, 胡健, 孙飞翔, 张立伟. 水源涵养与水文调节: 和而不同的陆地生态系统水文服务. 生态学报, 2015, 35(15): 5191-5196.

[50］徐浩田, 周林飞, 成遣. 基于 PSR 模型的凌河口湿地生态系统健康评价与预警研究. 生态学报, 2017, 37(24): 8264-8274.

[51］秦趣, 黄艳, 崔小平. 基于 PSR 模型的云贵高原湿地生态系统健康评价. 水生态学杂志, 2019, 40(5): 26-31.

[52］谢放尖, 吴长年, 黄戟, 赵剑, 张汉明. 人工湿地生态系统健康评价实证研究. 环境保护科学, 2008, 34(5) : 49-52, 68-68.

[53］崔保山, 杨志峰. 湿地生态系统健康评价指标体系 II. 方法与案例. 生态学报, 2002, 22(8)：1231-1239.

[54] 朱锦, 朱卫红, 金日, 张达, 于瑶. 中国图们江流域湿地生态系统健康评价研究. 湿地科学, 2019, 17(3) : 344-351.

[55] 高静活, 王晓云, 李卫平, 于玲红, 苗春琳, 樊爱萍. 包头南海湿地生态系统健康评价. 湿地科学, 2017, 15(2): 207-213.

[56] 汪金来, 凌宇, 蔡成瑞, 杨小艳, 陈龙高. 基于人粮关系的淮海经济区土地资源承载力时空变化. 江苏师范大学学报: 自然科学版, 2020, 38(1): 12- 16 .

[57] 王瑞杰, 吴林荣, 间峰. 基于人粮关系的鄂尔多斯吪砂岩区土地资源承载力变化特征. 水土保持通报, 2019, 39(6)：142-148，154-154.

[58] 陈风, 苏少川, 陈妍, 李宁, 王韧, 游巍斌, 何东进. 基于 PSR 模型的闽东滨海湿地生态系统健康评价. 湿地科学与管理, 2020, 16(3)： 25-29.

[59］徐国荣，马维伟，李广，张宏奎. 基于 PSR 模型的甘南尔海湿地生态系统健康评价. 水土保持通报, 2019, 39(6)：275-280.

[60］冯倩, 刘聚涛, 韩柳, 温春云, 胡芳. 鄱阳湖国家湿地公园湿地生态系统健康评价研究. 水生态学杂志, 2016, 37(4) : 48-54.

６1］易凤佳, 黄端, 刘建红, 邱娟, 施媛媛, 李仁东. 汉江流域湿地变化及其生态健康评价. 地球信息科学学报, 2017, 19(1): 70-79.

[62] 高卓, 何釒, 胡祖芳, 罗荐文. 层次分析法在生态系统健康评价指标体系中的应用. 中央民族大学学报：自然科学版，2017，26(1)： 61-66.

[63] 邓雪, 李家铭, 曾浩健, 陈俊羊, 赵俊峰. 层次分析法权重计算方法分析及其应用研究. 数学的实践与认识, 2012, 42(7): 93-100.

[64] 常建娥, 蒋太立. 层次分析法确定权重的研究. 武汉理工大学学报: 信息与管理工程版, 2007, 29(1)：153-156.

６55］陆志强, 李吉鹏, 章耕耘, 马丽. 基于可变模糊评价模型的东山湾生态系统健康评价. 生态学报, 2015, 35(14)：4907-4919.

[66] 宋爽, 田大方, 毛鋔. 国家湿地公园社会功能评价指标体系构建及应用一一白渔泡国家湿地公园为例. 湿地科学, 2019, 17(2)： 237-243.

[67] 林波, 尚鹤, 姚斌, 陈展, 刘小楠. 湿地生态系统健康研究现状. 世界林业研究, 2009, 22(6) : 24-30.

[68］钟连秀, 路春燕, 王宗明, 刘明月, 陈远丽, 林晓晴, 苏颖, 贾明明. 基于 GIS 与 RS 的漳江口红树林湿地生态系统健康评价. 生态学杂 志, 2019, 38(8): 2553-2563.

[69］赵衡, 间旭, 王富强, 康萍萍. 基于 PSR 模型的三门峡库区湿地生态系统健康评价. 水资源保护, 2020, 36(4) : 21-25, 74-74.

[70] 徐烨, 杨帆, 颜昌宙. 基于景观格局分析的雄安城市湿地生态健康评价. 生态学报, 2020, 40(20): 7132-7142. 